\title{
Advances in the Treatment of Textile Effluents: A Review
}

\author{
Marco Antônio Covi Júnior, Andressa Graciele dos Santos, Elias de Paulo Silva, \\ Guilherme Franqueiro Maimoni, Helísa Naves Martins, Maria Luiza de Moura Assis, \\ Carmen Aparecida Cardoso Maia Camargo, Marcio Antonio Ferreira Camargo \\ University of State of Minas Gerais, Academic Unit of Passos, Passos, Brazil \\ Email: marcoantoniocovi@hotmail.com, andressag.santos0@gmail.com, Elias-Rz@hotmail.com, guilherme.crc@hotmail.com, \\ naveshelisa@gmail.com,maluumoura@hotmail.com, kkcamargo@yahoo.com.br, mcamargo2004@yahoo.com.br
}

How to cite this paper: Covi Jr., M.A., dos Santos, A.G., de Paulo Silva, E., Maimoni, G.F., Martins, H.N., de Moura Assis, M.L., Camargo, C.A.C.M. and Camargo, M.A.F. (2019) Advances in the Treatment of Textile Effluents: A Review. Open Access Library Journal, 6: e5549.

https://doi.org/10.4236/oalib.1105549

Received: June 17, 2019

Accepted: July 9, 2019

Published: July 12, 2019

Copyright (C) 2019 by author(s) and Open Access Library Inc.

This work is licensed under the Creative Commons Attribution International License (CC BY 4.0).

http://creativecommons.org/licenses/by/4.0/

\begin{abstract}
The textile industry moves the economy of several countries, being of great importance for the internal market and also for the external market, but it is considered one of the industries that consume a greater volume of water in its productive process, being one of the largest producers of effluents. Effluents from the textile industries carry toxic, mutagenic and potentially carcinogenic substances, and are resistant to chemical and/or biological degradation, preventing traditional effluent treatment methodologies from removing significant quantities of these molecules, compromising the quality of receiving water bodies. The present work aims to demonstrate the conventional methodologies used in the treatment of effluents from textile industries and present new technologies discovered for this purpose and present a greater efficiency in the removal of the dyes used in the productive chain of these industries.
\end{abstract}

\section{Subject Areas \\ Environmental Chemistry}

\section{Keywords}

Industrial Effluents, Effluents Treatment, Textile Effluents

\section{Introduction}

Due to the great diversity of the existing industrial processes, the industrial effluents are extremely different from each other, being derived from the use of water for non domestic purposes within the industry, acquiring its own charac- 
teristics due to the industrial processes employed [1].

These types of effluents do not allow the determination of a standard treatment methodology for all industrial effluents. The industrial effluents can be classified into two groups, the first being organic industrial waste and the second as inorganic industrial waste. Organic industrial wastes are mainly effluents composed of protein compounds ( $40 \%$ to $60 \%$ ), carbohydrates ( $25 \%$ to $50 \%$ ), fats and oils (10\%), urea, dyes and pesticides, the latter in a smaller quantity, etc. Inorganic industrial waste consists of solid materials such as sand and fibers, and heavy metals chemicals [2].

In Brazil, there are federal, state and municipal laws that legislate on the disposal and treatment of industrial effluents. Conama Resolution No. 6 of June 15, 1988, repealed by Resolution No. 313 of 2002, in its Article 1, establishes that "in the process of environmental licensing of industrial activities, the residues generated should be subject to specific control" [3]. Conama Resolution No. 20, dated June 18, 1986 classifies the waters, determining the limits and/or conditions for each type of framing class [4]. Resolution No. 430, of May 13, 2011, which complements and alters Resolution No. 357/2005, provides for the conditions and standards for the discharge of effluents [5].

The textile industry moves the economy of several countries, being of great importance for the internal market and also for the external market, but it is considered one of the industries that consume a greater volume of water in its productive process, being one of the largest producers of effluents.

Azo dyes are among the dyes used by the textile industry in dyeing and finishing fabrics. In chemical terms, the azo dyes "carry in their structure the chemical group $R N=N-R^{\prime}$, wherein $N=N$ refers to the azo group and $R$ and $R$ 'may be either an aryl group or an alkyl group" [1].

These substances are toxic, mutagenic and potentially carcinogenic. Another problem is that these compounds have resistance to chemical and/or biological degradation, which hinders the success of the methodologies traditionally employed in the treatment of textile effluents, even after treating significant amounts of these molecules, causing the water with regard to the quality parameter [6].

Azo dyes also cause high turbidity when present in the textile effluent, damaging aquatic life in general. Normally, due to the great complexity of the organic molecules present in the textile effluent, it has low biodegradability [1].

\section{Conventional Processes for the Treatment of Industrial Effluents}

Conventional treatment processes are usually not capable of degrading the molecular structures of the dyes because they have stable characteristics and are difficult to biodegrade [7].

The conventional techniques of treatment by the coagulation processes, flotation separation or sedimentation, have efficiency in the removal of particulate matter, but in the removal of color and dissolved organic compounds they are 
deficient [7] [8].

The first step in the treatment of effluent from the textile industry is the fine grating (fibrils), whose opening varies from 1 to $2 \mathrm{~mm}$, whose purpose is to remove debris from fabrics and eventual coarse solids from the production process that can obstruct pipes and damaging the PTS system. Afterwards, the effluent is sent to the equalization tank, which has a specific volume to regulate the flow rate of the treatment, presenting red coloration and a few hours later completely blue or yellow due to the variety of tissues produced. In the equalization/decanter tank one or more surface aerators are used to promote the effluent mixture and assist in $\mathrm{pH}$ regulation (ranges from 6.0 to 11.5), then initiate physico-chemical or biological treatment where the $\mathrm{pH}$ is reduced to 7 , by the dosage of acid solution or via the addition of carbon dioxide. The tank should still be planned according to the volume of wastewater produced over time, which can be used the Parshall gauge with ultrasonic sensor to perform the measurement [9].

The removal of color can be achieved in biological and non-biological processes, being the most attractive from the economic point of view. The most used treatments are the chemical physicists (initially performed) for the very colored and little biodegradable effluents, by the addition of coagulants based on ferric chloride or aluminum sulphate; and biological when the biodegradable substances are dissolved.

The biological processes represented by the aerobic activated sludge system are used more frequently to meet legal and environmental requirements, including economic cost issues [10].

This process consists of the agitation of the effluents in the presence of microorganisms and air, to metabolize and flocculate part of the organic matter. This system presents about $80 \%$ efficiency in the removal of dye loading, but the accumulation of sludge has become a problem because it cannot be reused because of high dye content [8].

These systems have a relatively high efficiency, allowing the reduction of the Chemical Oxygen Demand (COD) and the Biological Oxygen Demand (BOD), but they are inefficient in the removal of color from the aqueous currents. In both techniques or when combined the wastes generated by the treatment process should be densified and dewatered in filter press or centrifuge for final material disposal.

The effluent treatment system of the textile industry for activated sludge can be applied to treat large volumes of effluents, and can be associated with other systems in order to improve treatment efficiency [10].

As for the technologies available for the treatment of textile effluents, the following processes have been proven: biodegradation, ozone treatment, physical processes of activated carbon adsorption and membranes utilization, heterolytic photocatalysis processes, electrocoagulation and the use of combined processes. 


\subsection{Physical Processes}

Usually used as foot-treatment or as a precursor to biological processes, as it is used in sanitation, the physical and chemical processes aim to reduce the pollutant loads or removing compounds that may disrupt the biological process.

According to Ferreira (2004) [11], physical processes are every method that uses facilities to separate or combine elements, which are by physical processes (without chemicals), such as filtration and decantation.

Physical methods for effluent treatment include adsorption with activated carbon and various types of materials such as peat, fly ash and coal mixture, wood chips, clay and rice husks; membrane filtration, ion exchange, irradiation and coagulation/flocculation [12].

The main physical processes currently under study for the treatment of textile effluent are:

\subsection{Adsorption}

The adsorption method is one of the main processes currently under study. It is very efficient for small volumes of effluent, but it is a slow and costly technique. The most used adsorbent is activated charcoal, which can originate in the most diverse types of material, such as: wood, peat, coconut and walnut shells, anthracite, bituminous coal, etc. [13].

The method of operation of this process involves the contact between a solid and a fluid where the mass transfer of the liquid or gaseous phase to the surface of the solid occurs. This is due to the uncompensated attractive forces on the surface of the solid. The adsorption efficiency depends on some variables such as: $\mathrm{pH}$, temperature, polarity of the substance, pressure and surface area [14].

Within the adsorption process, the bonding forces between the adsorbate and adsorbent molecules designate how adsorption occurs, and this can be separated in two ways: physical and chemical (chemisorption) as shown in Table 1.

Therefore, to characterize the adsorption effectiveness of different types of adsorbents, it is necessary to obtain data. One can also study, parameters that can affect the process, among them, the variables already mentioned in the context.

Table 1. Differences between the physical and chemical adsorption process.

\begin{tabular}{|c|c|}
\hline Physical adsorption & Chemical adsorption \\
\hline Non-specific & Highly specific \\
\hline \multicolumn{2}{|l|}{ Temperature sensitive } \\
\hline Occurs through intermolecular interactions & Occurs through chemical bonds \\
\hline $\begin{array}{l}\text { The rate is limited by mass transfer since } \\
\text { there is no energy barrier of activation }\end{array}$ & $\begin{array}{l}\text { The rate is low due to the existence } \\
\text { of an activation barrier } \\
\text { (associated with chemical kinetics) }\end{array}$ \\
\hline Monolayer or multiple layers & Monolayer on solid surface \\
\hline Low adsorption enthalpy variation & High enthalpy change of adsorption \\
\hline
\end{tabular}

Source: Adapted from Radecki (1999) [15] and Ruthven (1984) [16]. 


\subsection{Membrane}

Among the various filter media available on the market, membranes are one of the most known and used. This is because they are able to separate substances that conventional filters cannot contain.

This separation method has the ability to clarify, concentrate and, above all, continuously separate the dye from the effluent, besides allowing the treatment of large volumes of effluents, but the costs are high and maintenance is very problematic due to the difficulty of cleaning the filter parts. Their process is based on the effective separation of dye molecules of sizes large enough to be separated from the effluent [13].

According to Farrugia apud Carvalho (2013) [17], "membranes are physical barriers capable of controlling the passage or retention of different substances, depending on the problem of treatability to be solved". Because they have pores of varying sizes, the membranes serve both to separate particles and to fractionate molecules of different weights. The membranes can be made from various organic and inorganic materials, such as polymers, ceramics, silicon carbide, stainless steel, among others.

Depending on the size of the pores, each membrane receives a classification and an application. Currently, in the market, the existing types are:

\subsection{Reverse Osmosis}

The Reverse Osmosis membrane has small pores through which only small molecules such as water pass through. By having the ability to hold up to ions, this type of membrane is applied for water purification.

\subsection{Ultrafiltration}

This category of membranes is used for processes of concentration, dialysis and purification, especially in works with macromolecules, such as proteins. One of the most recurring uses for ultrafiltration membranes is in the treatment of water for reuse. With ultrafiltration membranes it is possible to achieve high quality standards, sometimes higher than those of drinking water.

\subsection{Nanofiltration}

This type of membrane is thinner than ultrafiltration, but not as thin as reverse osmosis. The pore diameter is of the order of $0.001 \mu \mathrm{m}$. The separation mechanism is not only filtration, it also involves solubility and diffusion. The osmotic pressure begins to influence the flow of solvent through the membrane.

\subsection{Microfiltration}

The microfiltration membrane is used for the separation of suspended solids in water and can also be used as protection for nanofiltration and reverse osmosis membranes. Microfiltration membranes are a safe physical barrier to retention of microorganism, bacteria and suspended matter, but allowing passage of water 
and soluble components present.

Its application is even more efficient in the use of membrane bioreactors (MBR), according to Farrugia (2013) [17] in this process the membranes replace the normally used decantation process, promoting a $100 \%$ retention of the biomass and guaranteeing a better treated water that can be used in secondary reuse (discharge, cooling towers, irrigation, washing in general, among other uses).

Its shelf life cannot be determined; typically, this characteristic is measured by the filtration capacity of the membrane, which is influenced by the level of aggressiveness that the membrane will have to endure during operations. According to Farrugia apud Carvalho (2013) [17], on average, a membrane of Ultrafiltration, Nanofiltration and Reverse Osmosis lasts three years, but the material from which they are made also influences greatly the useful life. "It can vary from 1 to 5 years, depending on the operating conditions and what is being processed by the membranes."

\subsection{Biodegradation}

When not properly treated, effluents from the dyeing process of textile fibers can modify the ecosystem, reducing the transparency of the water and the penetration of solar radiation, which can modify the photosynthetic activity and the gas solubility regime.

The great motivation of all researchers involved in biodegradation studies can be expressed by the continuous search for versatile microorganisms capable of efficiently degrading large numbers of pollutants at a low operating cost. In practice, it is very difficult mainly because of the diversity, concentration and composition of chemical species present in each effluent.

Several organisms can be used in degradation as bacteria, fungi or plants, and their efficiency depends in many cases on the structure of the molecule and on the presence of enzymes that are able to degrade the product [18].

Biodegradation refers to the process where a particular microorganism in the environment is able to convert a complex chemical molecule into a simpler molecule. These molecules are used by these microorganisms as a source of carbon in order to obtain energy necessary for their growth and maintenance of metabolism [19].

Bacterial degradation involves an enzymatic step where cleavage of azo bonds occurs from an azoreductase enzyme and an electron donor. The resulting products, for example, some aromatic amines can be degraded by the hydroxylase and oxygenase enzymes produced by these bacteria. However, many other by-products of the discoloration of solutions, such as amino benzene sulphonic or acidic sulfonylnaphthylamines are recalcitrant to the bacterial attack, since the sulfonyl groups correspond to a xenobiotic structural element, where its strongly charged anionic portion prevents the penetration of the compound through the bacterial membrane. Thus the application of bacteria in the treatment of azo dyes becomes somewhat restricted [20]. 
The use of bacteria such as Pseudomonas sp and Sphingomonassp have been reported in the degradation of dyes. These microorganisms are particularly useful for degradation of azocorates since it has the ability to carry out reductive cleavage in the azo bonds of this type of compound, a fact which is generally associated with the enzyme azoreductase.

On the other hand, fungi may degrade or even mineralize several recalcitrant organic substances due to their extracellular lignolytic system with low substrate specificity. The most used fungi in the biological treatments are the filamentous ones that are present abundantly in the environment, are able to quickly adapt their metabolism to different sources of carbon and nitrogen in the search for their survival [21].

This metabolic activity of fungi is obtained through the production of a large set of intra- and extracellular enzymes, capable of degrading complex organic pollutants such as poly aromatic hydrocarbons, organic residues, dye-containing effluents, among others. These enzymes are lignolytic, such as lignin peroxidase, manganese peroxidase and laccase [22]. The most used fungi are Phanerochaetechrysosporium, Aspergillusoryzae [23], Aspergillusterreus, Aspergillusniger [24]; Trametessp [25] among others.

Researchers have increased interest in the versatile white fungus Phanerochaetechrysosporium. This fungus has the capacity to mineralize, in addition to lignin, at least partially and in some cases completely, a variety of pollutants resistant to degradation [26].

The lignolytic system of this fungus is represented mainly by the enzymes lignin and manganese peroxidase, which are produced in media containing sources carbon and nitrogen. These enzymes have the ability to depolyelise lignin and a wide variety of other compounds.

The use of other fungi such as Pleorotusostreatus and Trametesversicolor for dye degradation has also been studied. These fungi are characterized as being good producers of laccase, a copper-dependent phenol oxidase enzyme. This lignolytic enzyme has the ability to catalyze demethylation reactions, which is an initial and important step in biodegradation processes of polymer chains, with subsequent decomposition of lignin macromolecules by the disruption of aromatic rings and $C_{a}-C_{b}$ bonds in phenolic structures. In oxidation processes of many compounds (mainly phenolic compounds) laccase presents a high specificity for a large number of xenobiotic compounds and industrial effluents [27].

Another recent alternative for the treatment of effluents and compounds resistant to degradation refers to the use of natural chelating agents, produced by some fungi and bacteria. These compounds, called siderophores, have a high affinity for metals, mainly iron, forming complexes of high stability. The biological function of siderophores is to sequester iron in environments with this deficiency.

There are basically two types of siderophores characterized so far, the catecholate type and the hydroxamate type. The presence of the catecholate type was detected in several lignolytic fungi, which was not so frequently observed with 
the hydroxamate type. Recent studies show very interesting results with some fungi and bacteria producing these compounds, demonstrating a mimetic activity of phenoloxidase, which allowed the discoloration of effluents and the degradation of compounds of difficult degradation [28].

\subsection{Treatment with Ozone}

A viable alternative both environmentally and economically for the treatment of textile effluents is the ozone process. This method has been shown to be effective in the discoloration of the effluent, in the oxidation of refractory compounds, in the removal of toxicity and in the increase of the biodegradability of the effluent, and also in the COD reduction, making it more suitable to be released back into the environment. What makes its application even more attractive, besides the fact that the system does not generate solid waste, is to be easy to install and operate.

Ozonation is part of the advanced oxidative processes (AOPs), which are technologies that use an oxidizing agent (such as $\mathrm{O}_{3}, \mathrm{H}_{2} \mathrm{O}_{2}$ ) and/or catalysts ( $\mathrm{Fe}$, $\mathrm{Mn}$ ) in the presence or absence of irradiation source, for hydroxyl radicals $(\mathrm{OH}-)$, highly reactive, capable of mineralizing organic substances present in industrial effluents [29].

Ozone is able to react with a large class of organic compounds, due to its high oxidation potential, higher than that of known oxidizing compounds, such as $\mathrm{H}_{2} \mathrm{O}_{2}$ and chlorine. In certain conditions, ozone leads to the formation of a hydroxyl radical, whose oxidation potential is even higher (Almeida et al., 2004).

Ozone is a gas that may be colorless to unstable blue, has water solubility for a partial pressure equal to $1 \mathrm{~atm}$ in the gas phase of $570 \mathrm{mg} \cdot \mathrm{L}^{-1}-1^{\circ} \mathrm{C}$ at $20^{\circ} \mathrm{C}$, i.e. 12 times lower than chlorine under the same conditions [30]. This gas can be produced in three different ways: corona discharge, exposure of $\mathrm{O}_{2}$ to ultraviolet light and electrolysis of perchloric acid, with the corona discharge being the most used commercially.

The advantages of using ozone, according to Ornelas and Aisse (2004) [31] are:

- Ozone is 3.125 times faster than chlorine in inactivation of bacteria, being 100 times more soluble in water;

- Does not produce toxins in water;

- It is generated at the place of use;

- When consumed, it decomposes naturally into oxygen;

- Transportation, handling and inventory costs are not required;

- In the treatment of water and food it configures technology of easy handling, presenting satisfactory results;

- Organic by-products of ozonation of domestic effluents treated at secondary level have little or no acute toxicity;

- Color reduction, even at low dosages required for disinfection, has been shown to be effective.

The main disadvantage of the ozonation process is the toxicity of the formed 
products. The dye molecules contain nitrogen, chlorine and sulfur $(\mathrm{N}, \mathrm{Cl}, \mathrm{S})$ and the oxidation of these molecules can generate new molecules of toxicity superior to that of the original. Ozone efficiency in the removal of ammonia is low [32].

Although ozone production costs have declined in recent years, ozonation is still a costly process. Other disadvantages of the process are the high reactivity and instability of the oxidizing agent, preventing its transport, storage and long-term residence in water. In cases of compounds that are difficult to break down, the cost-benefit ratio of ozonation to conversion to $\mathrm{CO}_{2}$ and $\mathrm{H}_{2} \mathrm{O}$ is not always favorable because of high dosages. In cases such as this, ozone can be applied as a pretreatment [33].

There are two ways, either directly or indirectly, to carry out the oxidation of pollutants or effluents:

- Direct Oxidation: In this process the ozone molecule can react directly with other organic or inorganic molecules via electrophilic addition. The electrophilic attack of ozone can happen to atoms with a negative charge density $(\mathrm{N}$, $\mathrm{P}, \mathrm{O}$ or nucleophilic carbons) or to double or triple bonds of carbonocarbon, carbon-nitrogen and nitrogen-nitrogen types.

- Indirect Oxidation: With this method ozone can react through radical reaction (mainly $\mathrm{OH}$ ) that is generated by the decomposition of ozone. The hydroxyl radical is a powerful and non-selective oxidant $\left(\mathrm{E}^{\circ}=2.80 \mathrm{~V}\right)$ that can react through three distinct mechanisms:

- abstraction of hydrogen;

- transfer of electrons; or

- radical addition. The secondary radicals formed during these reactions can again react with ozone or the other compounds.

According to Rodrigues (2004) [33], ozone studies in the treatment of effluents from the textile industry demonstrate the improvement in the coagulation and flocculation process due to the formation of carboxylic and phenolic groups after ozonization, which helps the adsorption of organic compounds and hydroxides metallic.

\subsection{Heterogeneous Photocatalysis Process}

Pruden and Ollis (1983) [34] demonstrated for the first time the application of photocatalysis for decontamination of waste water, oxidizing chloroform by irradiating a suspension of this compound with titanium dioxide $\left(\mathrm{TiO}_{2}\right)$ by $\mathrm{UV}$ light. Since then, this technique has been heavily researched due to its potential for destruction of pollutants [1].

In general, the process is based on the irradiation of a photocatalyst (inorganic semiconductor), in this case $\mathrm{TiO}_{2}$, whose photon energy must be greater than or equal to band gap energy to excite the electron) of the semiconductor to trigger the electronic transition. Thus, under irradiation, an electron is promoted from the valence band (BV) to the conduction band (BC) forming oxidizing and reducing sites that catalyze chemical reactions, oxidizing organic compounds to 
$\mathrm{CO}_{2}$ and $\mathrm{H}_{2} \mathrm{O}$, and reducing dissolved metals or other species present [11].

This process has the advantage that depending on the semiconductor used, sunlight can be used as the energy source for semiconductor activation. Many organic compounds are degradable in this process, for example alkanes, chloraliphatics, alcohols, carboxylic acids, phenols, chlorophenols, herbicides, surfactants and dyes, being destroyed with good efficiency over conventional oxidation methods. $\mathrm{TiO}_{2}$ stands out among the semiconductor oxides, being the most used because of their non-toxic nature, low cost, water insolubility, photostability, chemical stability over a wide range of $\mathrm{pH}$ and possibility of activation by sunlight [1].

Although it is a highly efficient process, allowing the rapid mineralization of chemical compounds, several practical problems limit the use of this process on a large scale. Some limitations are related to the need for artificial sources of radiation, since most of the photocatalysts present a band gap corresponding to the ultraviolet region; difficulties in the penetration of radiation into the reaction medium and difficulties in separating thephotocatalysts, since these are used in the form of fine suspensions and; difficulties in the implementation of large-scale continuous systems, mainly due to the previous drawbacks [8].

On an industrial scale, the limitations are in relation to the use of ultraviolet light that makes treatment expensive, due to the need to construct stations that use continuous sunlight; the immobilization of the semiconductor generates losses in the photocatalytic activity; and there is a need to separate the fine particles from the catalyst [35].

Some alternatives are being studied to solve the presented problems, some of them being the development of more efficient photocatalysts (doping); implementation of systems that operate with immobilized photocatalysts; and the use of photocatalysts that can be activated by sunlight or by sensitizing systems [8].

\section{Discussion}

According to the literature cited in the reference, for effluent treatment, a very effective solution is the use of combined processes in the treatment system. The methods used complement the treatment, since the processes, when carried out separately, may present deficiencies, which are remedied in the combined processes.

Among the various methods of treatment of effluents, three of them are the main factors, classifying them as physical, chemical and biological. To combine the treatment of an effluent with these factors together, one must have in definition the objective that one wishes to attain in the treatment.

In the treatment of textile effluents, the combined process method proved to be most suitable due to the presence of dyes in the effluent and which are highly resistant to degradation in conventional treatment systems.

Therefore, a greater emphasis was placed on methodologies that combine biological processes with other physical or physico-chemical alternatives, such as 
flocculation, adsorption or electrochemical oxidation.

With very promising results, the combination of advanced oxidative processes (AOPs), using hydrogen peroxide, ozone, ultraviolet light, $\mathrm{TiO}_{2}$, has been tested as an alternative to currently established treatment processes.

Physical processes using membrane technologies combined primarily with ozone have also received special attention because of the potential for reuse of water. In addition, the combination of biological processes (anaerobic-aerobic) is also useful as it allows for efficient discolouration, especially when azo dyes are present in this effluent.

In the tests carried out, white decomposition fungi, when combined with biological and chemical methods, are very efficient in the discoloration of textile effluents and dyes.

\section{Conclusions}

Due to the complexity and difficulty of treating textile and industrial effluents in general, new alternatives in methodologies for the treatment of these types of tailings have been frequently sought.

We currently have a diversity in physical, chemical and biological methods and the definition of the best or best methods to be used should be carried out safely observing the specific objectives to be achieved with the treatment.

With the current knowledge and results, following a technological vision regarding industrial effluents, we must constantly follow through clean technologies, a search to minimize the generation of waste, the objective should be to solve the problem inside the factory, in the point of generation, and not only after having already generated the effluent.

\section{Conflicts of Interest}

The authors declare no conflicts of interest regarding the publication of this paper.

\section{References}

[1] Lima, C.S. (2015) Photodecomposition and Removal Textile Effluent by Photocatalysis with Polypyrrole. Universidade Federal de Goiás, Instituto de Ciências Biológicas, Programa de Pós-Graduação em Ciências Biológicas, Goiânia.

[2] Archela, E., Carraro, A., Fernandes, F., Barros, O.N.F. and Archela, R.S. (2003) Considerations about the Generation of Liquids Sewage in Urban Centers. Geografia, 12, 517-525.

[3] Brasil, Resolução Conama nº 6 de 15 de junho de 1988. http://www.meioambiente.ufrn.br/wp-content/themes/pma/con006-88.pdf

[4] Brasil, Resolução Conama n 20, de 18 de junho de 1986. https://www.unaerp.br/documentos/2225-resolucao-conama-20-1986/file

[5] Brasil, Resolução $\mathrm{n}^{\circ}$ 430, de 13 de maio de 2011. Dispõe sobre as condições e padrões de lançamento de efluentes, complementa e altera a Resolução no 357, de 17 de março de 2005, do Conselho Nacional do Meio Ambiente-CONAMA. http://www.meiofiltrante.com.br/edicoes.asp? fase $=$ C\&id $=880$ 
[6] Freire, F.B. and Freitas, S.I. (2010) Evaluation of Color Removal of a Synthetic Textile Effluent. Engenharia Ambiental: Pesquisa e Tecnologia, 7, 241-249.

[7] Dalari, B.L.S.K., Menon, B.C., Hassemer, M.E.N. and Lapolli, F.R. (2017) Aplicação de eletrocoagulação no tratamento de efluente têxtil. In: Congresso ABES FENASAN.

[8] Kunz, A., Peralta-Zamora, P., Moraes, S.G. and Durán, N. (2002) New Tendencies on Textile Effluent Treatment. Revista Química Nova, 25, 78-82. https://doi.org/10.1590/S0100-40422002000100014

[9] Neto, H.M. (2014) Tratamento de efluentes nas indústrias têxteis. http://www.revistatae.com.br/7460-noticias

[10] Duarte, F.V. (2013) Métodos de tratamento de efluentes da indústria têxtil. Monografia com requisito parcial na obtenção do título de especialista em recursos hídricos e ambientais na Universidade Federal de Minas Gerais. Montes Claros.

[11] Ferreira, I.V.L. and Daniel, L.A. (2004) $\mathrm{TiO}_{2}$ Heterogeneous Photocatalysis in Secondary Wastewater Treatment. Engenharia Sanitaria e Ambiental, 9, 335-342.

https://doi.org/10.1590/S1413-41522004000400011

http://www.scielo.br/scielo.php?script=sci arttext\&pid=S1413-41522004000400011 \&lng=en\&nrm=iso

[12] Doble, M. and Kumar, A. (2005) Textile Effluent. In: Biotreatment of Industrial Effluents, Butterworth Heinemann, Oxford, 123-132. https://doi.org/10.1016/B978-075067838-4/50012-9

[13] Guarantini, C.I. and Zanoni, M.V.B. (1999) Corantes Têxteis. Química Nova, Campinas, 23, 71-78. http://www.higra.com.br/pt/a-higra https://doi.org/10.1590/S0100-40422000000100013

[14] Furlan, F.R. (2008) Avaliação da eficiência do processo de coagulação-floculação e adsorção no tratamento deefluentes têxteis. Dissertação (Mestrado em Engenharia Química), Universidade Federal de Santa Catarina, Florianópolis.

[15] Radecki, P.P. (1999) Emerging Separation and Separative Reaction Technologies for Process Waste Reduction: Adsorption and Membrane Systems. American Institute of Chemical Engineers, New York.

[16] Ruthven, D.M. (1984) Principles of Adsorption and Adsorptions Process. John Wiley \& Sons, New York.

[17] Farrugia, B. (2013) Membranas de Filtração. Tecnologia Eficiente Em Aplicações Diversas, Revista Meio Filtrante, Edição No 64. http://www.meiofiltrante.com.br/edicoes.asp?fase $=$ C\&id $=880$

[18] Meyer, U. (1978) Biodegradation of Synthetic Organic Colorants. In: Brown, A.W.A., Ed., Ecology of Pesticides, John Willey, New York, 525.

[19] Buratini, S.V. (2008) Biodegradação. In: Zagatto, P. and Bertoletti, E., Eds., Ecotoxicologia Aquática, Princípios e Aplicações, 2nd Edition, RiMa, São Carlos, $472 \mathrm{p}$.

[20] Tan, L., He, M., Song, L., Fu, X. and Shi, S. (2016) Aerobic Decolorization, Degradation and Detoxification of Azo Dyes by a Newly Isolated Salt-Tolerant Yeast Scheffersomyces Spartinae TLHS-SF1. Bioresourse Technology, 203, 287-294. https://doi.org/10.1016/j.biortech.2015.12.058

[21] Solís, M., Solís, A., Perez, H.I., Manjarrez, N. and Flores, M. (2012) Microbial Decolourization of Azo Dyes: A Review. Process Biochemistry, 47, 1723-1748. https://doi.org/10.1016/j.procbio.2012.08.014

[22] Saratale, R.G., Saratale, G.D., Chang, J.S. and Govindwar, S.P. (2011) Bacterial De- 
colorization and Degradation of Azo Dyes: A Review. Journal of the Taiwan institute of Chemical Engineers, 42, 138-157. https://doi.org/10.1016/j.jtice.2010.06.006

[23] Santos, G.C. and Corso, C.R. (2014) Comparative Analysis of Azo Dye Biodegradation by Aspergillus oryzae and Phanerochaete chrysosporium. Water, Air \& Soil Pollution, 225, 2026. https://doi.org/10.1007/s11270-014-2026-6

[24] Almeida, E.J.R. and Corso, C.R. (2014) Comparative Study of Toxicity of Azo Dye Procion Red MX-5B Following Biosorption and Biodegradation Treatments with the Fungi Aspergillusniger and Aspergillusterreus. Chemosphere, 112, 317-322. https://doi.org/10.1016/j.chemosphere.2014.04.060

[25] Zhang, H., Zhang, S., He, F., Qin, X., Zhang, X. and Yang, Y. (2016) Characterization of a Manganese Peroxidase from White-Rot Fungus Trametes sp. 48424 with Strong Ability of Degrading Different Types of Dyes and Polycyclic Aromatic Hydrocarbons. Journal of Hazardous Materials, 320, 265-277.

https://doi.org/10.1016/j.jhazmat.2016.07.065

[26] Paszczynski, A., Pasti, M.B., Goszczynski, S., Crawford, D.L. and Crawford, R.L. (1991) New Approach to Improve Degradation of Recalcitrant Azo Dyes by Streptomyces spp. and Phanerochaete chrysosporium. Enzyme and Microbial Technology, 13, 378-384. https://doi.org/10.1016/0141-0229(91)90198-J

[27] Duran, N. and Espósito, E. (2000) Potential Applications of Oxidative Enzymes and Phenoloxidase-Like Compounds in Wastewater and Soil Treatment: A Review. Applied Catalysis B: Environmental, 714, 1.

[28] Machuca, A., Aoyama, H. and Duran, N. (1999) Isolation and Partial Characterization of an Extracellular Low-Molecular Mass Component with High Phenoloxidase Activity from Thermoascus aurantiacus. Biochemical and Biophysical Research Communications, 256, 20-26. https://doi.org/10.1006/bbrc.1998.9927

[29] Araujo, F.V.d.F., Yokoyama, L. and Teixeira, L.A.C. (2006) Remoção de cor emsoluções de corantes reativos por oxidação com H2O2/UV. Química Nova, 29, 11-14. https://doi.org/10.1590/S0100-40422006000100003

[30] Silva, A.C. (2006) Degradação de corantes em meio salino por ozonização. Universidade Federal do Rio de Janeiro, Rio de Janeiro.

[31] Ornelas, A. and Aisse, M.M. (2004) Utilização do ozônio no tratamento de efluentes: Investigação experimental da taxa real de produção de ozônio. 2004. 38 f. Trabalho de Conclusão de Curso (Graduação), Curso de Engenharia Ambiental. Pontifícia Universidade Católica do Paraná, Curitiba.

[32] Beltrame, L.T.C.B. (2000) Caracterização de efluente têxtil e proposta de tratamento. 2000. 179 f. Dissertação (Mestrado em Engenharia Química), Centro de Tecnologia em Engenharia Química, Universidade Federal do Rio Grande do Norte, Natal.

[33] Rodrigues, F.S.F. (2004) Aplicação da ozonização e do reativo de fenton como prétratamento de chorume com os objetivos de redução da toxicidade e do impacto no processo biológico. 2004. 79 f. Dissertação (Mestrado em Engenharia Civil), Área de Recursos Hídricos, Instituto Alberto Luiz Coimbra (COPPE), Rio de Janeiro.

[34] Pruden, A.L. and Ollis, D.F. (1983) Photoassisted Heterogeneous Catalysis: The Degradation of Trichloroethylene in Water. Journal of Catalysis, 82, 404-417. https://doi.org/10.1016/0021-9517(83)90207-5

[35] Fioreze, M., Santos, E.P. and Schmachtenberg, N. (2014) Processos oxidativos avançados: Fundamentos e aplicação ambiental. Revista Eletrônica em Gestão, Educação e Tecnologia Ambiental-REGET/ Revista do Centro do Ciências Naturais e Exatas-UFSM, 18, 79-91. 